\title{
Lusioersily
}

\section{Public Relations and Corporate Social Responsibility}

Somerville, I., \& Wood, E. (2012). Public Relations and Corporate Social Responsibility. In A. Theaker (Ed.), The Public Relations Handbook (pp. 175-194). Routledge.

Link to publication record in Ulster University Research Portal

\section{Published in:}

The Public Relations Handbook

Publication Status:

Published (in print/issue): 01/01/2012

\section{Document Version}

Publisher's PDF, also known as Version of record

\section{General rights}

Copyright for the publications made accessible via Ulster University's Research Portal is retained by the author(s) and / or other copyright owners and it is a condition of accessing these publications that users recognise and abide by the legal requirements associated with these rights.

\section{Take down policy}

The Research Portal is Ulster University's institutional repository that provides access to Ulster's research outputs. Every effort has been made to ensure that content in the Research Portal does not infringe any person's rights, or applicable UK laws. If you discover content in the Research Portal that you believe breaches copyright or violates any law, please contact pure-support@ulster.ac.uk. 


\title{
Public Relations and Corporate Social Responsibility
}

\author{
Ian Somerville and Emma Wood
}

\section{Chapter introduction and aims}

Corporate social responsibility (CSR) is a key legitimising practice for business organisations in contemporary society. This chapter focuses on the relationship between this activity and public relations (PR), the main communication management tool of CSR. Explaining and justifying the practice of CSR is usually regarded as a public relations function because this is where the company meets the public outside of the usual roles of producers (or service providers) and customers. One thing that is immediately apparent when one examines the literature explaining and justifying most CSR programmes is that the PR discourse in relation to CSR has utilised the language of the main ethical doctrines which have played a key role in debates about ethics since the Enlightenment. The ethical perspectives of utilitarianism and deontology are particularly apparent in underpinning concepts which tend to be used in describing or justifying the activity in CSR reporting. This leads to significant claims for corporate social responsibility programmes. For example, companies may maintain that such activity is the fulfilment of the duties and responsibilities that they have to the wider community, or that they contribute to the common good by benefiting both the company and society. The first part of the chapter outlines some of the main theoretical debates in respect to CSR and discusses the arguments for and against CSR. The second part of the chapter analyses how ethical concepts and the language used to express them in PR discourse relate to the actual practice of CSR. This is followed by a discussion of the issues surrounding CSR evaluation, reporting and stakeholder engagement and the role PR might play in these key tasks. The chapter ends with a case study of CSR in the banking industry following the 2009 'credit crunch' and subsequent collapse of much of the global financial sector. 


\section{Socially responsible business? Definitional and theoretical issues}

\section{Defining corporate social responsibility}

Definitions of CSR differ widely, ranging from the idea of charitable giving to the notion that business can help government achieve everything from social inclusion to environmental protection. Many definitions frame CSR activity as an intervention in society 'To be socially responsible corporations must co-operate with other groups - such as competitors, nonprofits and government agencies to help solve social problems' (Bowie 1993 quoted in Daugherty 2001: 389). Other definitions, such as that offered by the UK government, extend the responsibility to include the environment, people (employees and customers) and the economy:

The Government sees CSR as the business contribution to our sustainable development goals. Essentially it is about how business takes account of its economic, social and environmental impacts in the way it operates - maximising the benefits and minimising the downsides. Specifically we see CSR as the voluntary actions that business can take, over and above compliance with minimum legal requirements, to address both its own competitive interests and the interests of wider society' (see www.csr.gov.uk/whatiscsr.html).

While some argue that the concept is defined in so many different ways that it is practically meaningless (Sen and Bhattacharya: 2001) we would suggest at the very least CSR involves the idea of business being proactive in its relationship with a range of social actors and doing more than just trying to avoid transgressing widely accepted ethical rules or obeying the law. The term 'social responsibility' implies that business is motivated by more than just self-interest and is, in fact, an activity that aims to promote the interest of society at large. This can be differentiated from, for example, corporate sponsorship where 'the company's managers will expect a tangible return for their money' (Varey 1997: 118).

The following two sections discuss widely contrasting views of CSR. In some senses they represent the extreme poles of opinion on this issue. In practice the attitude of most business organisations to CSR will occupy a position somewhere between the two. Ethical doctrines play a role in justifying both perspectives. For example, Milton Friedman, who rejected the concept of CSR, attempts to justify his 'free-market approach' to some extent from a utilitarian standpoint. His position appears to be a vague 
echo of Adam Smith's 'invisible hand' theory of capitalism - that an unregulated free market, while proving disastrous for some, ultimately works to benefit the majority in society. On the other side of the debate CSR is viewed as a necessary and integral part of the 'stakeholder approach', an approach which is ultimately justified from a Kantian perspective.

\section{The social responsibility of business is to increase profits}

Milton Friedman, the economist and advocate of laissez-faire capitalism, argued against the idea that business has a social responsibility in the sense defined in the section above. He claimed that 'there is one and only one social responsibility of business - to use its resources and engage in activities designed to increase its profits' (Friedman 1993: 254). Friedman insists that it is wrong to suggest that corporations can have social responsibilities, for him only individuals can have responsibilities. He claims that the actual responsibilities of the corporation should be narrowly defined and limited to making 'as much money as possible while conforming to the basic rules of the society, both those embodied in law and those embodied in ethical custom (Friedman 1993: 249). By claiming that businesses have only one social responsibility, to maximise their profits, Friedman is in effect saying they have no social responsibilities in the generally accepted sense of the term. He does not say that moral rules have no place in relation to business practice, in fact while pursuing profits business must conform to what he refers to as 'ethical custom'. As Chryssides and Kaler (1993) point out he seems to be making a distinction between first and second order ethical rules, the basic moral rules of society (an obligatory first order) and social responsibility precepts (an optional second order). He does not elaborate on what the rules based on ethical custom are, but he does give some indication as to what the second order rules might involve. For instance Friedman castigates businessmen for 'preaching pure and unadulterated socialism' when they speak of 'responsibilities for providing employment, eliminating discrimination, avoiding pollution and whatever else may be the catchwords of the contemporary crop of reformers' (1993: 249).

According to Friedman those who 'preach' the doctrine of social responsibility are making two claims both of which he disagrees with. These are, firstly that business 
must actively seek to do good, that is, not just avoid transgressing 'ethical custom'. Secondly, this 'good' must not be done for profit, that is, it must not be done with selfinterest in mind (if this was the motivation Friedman would have no objection to it). This raises an important question, which is, is actively seeking to do good easily distinguishable from the mere avoidance of doing evil? Friedman seems to believe this to be the case but it is difficult to see how the examples that he points to demonstrate this and indeed overall his position appears to be riddled with flawed arguments. It could be agreed that some of the examples he lists, 'eliminating discrimination' or 'avoiding pollution' are doing 'good', but at the same time they are actions which are intended to eliminate what are widely perceived to be social or environmental evils. Thus ironically what Friedman's own examples actually illustrate is that on many occasions the moral choice is between doing good or, by default, doing evil. Chryssides and Kaler note:

Friedman's assumption of a neat division between 'ethical custom' and business social responsibility takes too narrow a view of both. The first cannot be confined to simply the passive avoidance of evil or the second to just the active pursuit of good because very often good and evil are simply two sides of the same moral coin. Friedman is therefore wrong to assume that acceptance of 'ethical custom' has no implication for the adoption of socially responsible policies by business. Clearly it has; if only because such is the power of business over people's lives that its failure to do good will very often result in great evils being permitted to flourish (1993: 232).

It is not only Friedman's conceptual understanding of CSR which is flawed, there are also problems with the arguments he presents in respect to what he perceives to be the responsibilities of a corporation. One of his key arguments, sometimes referred to as 'the agency argument' (Chryssides and Kaler 1993: 234), is that managers of corporations are merely agents of the shareholders in the companies they work for. Friedman states 'In a free-enterprise, private-property system, a corporate executive is an employee of the owners of the business. He has direct responsibility to his employers. That responsibility is to conduct the business in accordance with their desires' (1993: 249). In other words the owners of the corporation, the shareholders, are the only people to which managers are accountable and the only responsibility managers have is to act in their interests. This means maximising profits so that the shareholder will make as much money as possible from their investment. Friedman presents his premise about a manager's role vis-à-vis the 
shareholders as a 'statement of legal fact' (Chryssides and Kaler 1993: 234). Clearely Friedman is correct to state that the managers of a corporation have a primary duty to serve the interests of the shareholders. However, his attempt to imply that this is a straightforward issue of legality is completely spurious. In both British and US law the corporation is a separate legal entity and is not identified solely with any particular group - employees, shareholders or directors (Chryssides and Kaler 1993: 229). Managers therefore are not directly the 'agents' of the shareholders in the way that Friedman wishes to imply, although, shareholders are, in roundabout way, the owners of the business. Friedman's assertion that the interests of the corporation ought to be exclusively identified with its shareholders must be seen in the context of his advocacy of the values of free enterprise. These values involve a combination of ethical egoism and, as we noted above, a rudimentary version of classical utilitarianism which makes the assumption that if everyone pursues their own self-interest within a free market, the result is the greatest happiness, or economic well being, for the greatest number of actors within that market. Friedman's argument that only the interests of shareholders are important is, of course, something upon which there is not universal agreement. There is, in fact, an argument that the managers should act, in some senses, as the 'agent' of all groups associated with the corporation and not just the shareholders. Those who support this view reject Friedman's 'stockholder' or 'shareholder' model in favour of what usually referred to as the 'stakeholder' model.

\section{Kantian capitalism and the stakeholder approach}

The 'stakeholder' model is so named because those who propose it argue that the task of the corporate manager is to balance the interests of the different groups who have a 'stake' in the company. The interest of the shareholders in increasing their profits is only one interest, albeit an important one, amongst many that the manager must consider. This model requires the corporation to take account of its social responsibilities and to consider all of its stakeholders when developing business strategies. Evan and Freeman (1993) argue from a Kantian perspective for the adoption of the stakeholder model. They employ Kant's categorical imperative: 'Never use people simply as a means to an end; always treat yourself and others as beings with infinite value' (Deinhart's formulation 
2000: 117-8) to argue that corporations have a duty never to treat any human beings as if they have only an instrumental value to the business. In fact they go on to argue that all groups affected by a corporation should play a role in determining company policy. Evan and Freeman state this deontological or Kantian ethical doctrine explicitly:

We can revitalize the concept of managerial capitalism by replacing the notion that managers have a duty to stockholders with the concept that managers bear a fiduciary relationship to stakeholders. Stakeholders are those groups who have a stake in or claim on the firm. Specifically we include suppliers, customers, employees, stockholders and the local community, as well as management in its role as agent for these groups. We argue that the legal, economic, political, and moral challenges to the currently received theory of the firm, as a nexus of contracts among the owners of the factors of production and customers, require us to revise this concept along essentially Kantian lines. That is, each of these stakeholder groups has a right not to be treated as a means to some end, and therefore must participate in determining the future direction of the firm in which they have a stake (1993: 255).

They argue that, in the US, changes in the legal system have been progressively circumscribing the idea that the corporation is only run in the interests of the 'stockholders'. They point to a number of legal cases in the US which show that although stockholders' interests are still paramount, other interests, customers, suppliers, local communities and employees have increasingly secured protection under the law (Evan and Freeman 1993: 255-57). Friedman's viewpoint, they would argue, is slowly being overtaken by changes, in legislation and business thinking, more in line with a stakeholder approach.

In the stakeholder model the role of the corporation co-ordinates stakeholder interests. It is through the corporation that each stakeholder group makes itself better off through voluntary exchanges. They argue that the 'corporation serves at the pleasure of its stakeholders, and none may be used as a means to the ends of another without full rights of participation in that decision' (Evan and Freeman 1993: 262). From the stakeholder perspective corporate social responsibility is not an optional extra it is integral to the responsibilities of the company and the company must pay as much attention to its social duties as it does to maximising its profits. 


\section{The practice of corporate social responsibility}

This part of the chapter will analyse the practice of CSR by examining the language corporations use to explain this increasingly important corporate activity. It will then go on to discuss key recent issues surrounding CSR reporting and evaluation utilising recent academic analysis and practitioner research. Firstly, however, it is important to locate the role of PR within the practice of social responsibility. When business organisations decide to involve themselves in local community initiatives there is usually an attempt to construct a narrative to explain the organisation's actions. This task of explanation is usually allocated to the company's PR department. This is hardly surprising since public relations specialists frequently play a key role in setting up CSR programmes in the first place. It is also clear that the evaluation and reporting of CSR policies and practices is increasingly a function of PR departments or consultancies.

\section{Public relations and corporate social responsibility}

L'Etang notes that CSR 'is often managed by public relations practitioners for public relations ends, and therefore corporate social responsibility is seen as part of the public relations portfolio and as a technique to establish relations with particular groups (for example, in the local community) and to enhance reputation with key stakeholders' (2006: 414). There is however another key reason why PR specialists have tended to be associated with CSR, namely, the claim that PR can be a mechanism within liberal, pluralist society to enable the realisation of 'laudible social goals' (Gandy 1992: 133). For J.A. Pimlot the historian of PR in the US, the activity is intimately connected with what he views as democratic ideals. He writes: 'They [the public relations specialists] are experts in popularizing information...the better the job of popularization, the more smoothly will society function' (quoted in Pearson 1992: 257). Heath argues that 'professional communicators have a major voice in the marketplace of ideas' but that ultimately these voices 'compete to achieve cooperation - the collective and coordinated actions of people in society' (1992: 20). Broom goes further and argues that PR practitioners 'must operate as moral agents in society' and they must be prepared to place 
'public service and social responsibility over personal gains and special private interests' (2009: 151-2).

It is clear then that there is a significant strand within PR theorising which claims that the practice can have a positive contribution within society, although this usually comes with the proviso that practice needs to be transformed (Grunig 1989). It almost goes without saying that there is bound to be a tension between this conception of PR serving the interests of society and the requirement that it serves the interests of the corporation (Kim and Reber 2008). L'Etang notes that the 'area of corporate social responsibility thus highlights a dilemma which arises generally in the role of public relations: the tension between organisational goals and declared responsibility for "the public interest" (2006: 416). This tension between responsibility to the needs of the company and responsibility to the needs of society is sometimes revealed by the language used in corporate documents which attempt to explain the practice of CSR.

\section{The language of corporate social responsibility}

Companies frequently justify their CSR programmes with the utilitarian argument that 'everyone benefits' in the sense that the company's reputation is enhanced and a local community materially benefited. Neil Shaw, a former chairman of Tate \& Lyle plc. explains the mutual benefits of community programmes:

Our community activities, both in the UK and abroad, focus particularly on initiatives in the localities of our plants and the provision of direct assistance for individuals seeking further educational attainment. In addition, we also encourage secondment of employees to particular projects in the belief that, not only can this make a worthwhile contribution to community activities, but in doing so, the experience will enable volunteers to develop their own management potential (quoted in Newman 1995: 99).

Some commentators (L'Etang: 2006) note that while CSR programmes are indeed justified on utilitarian grounds there is in many instances little attempt to actually measure and evaluate the effects of such programmes. L'Etang points out that if such

evaluation is lacking then companies 'will not be in a position to claim that they have contributed to the general 'happiness'. In short, CSR justified on utilitarian grounds needs to demonstrate cost-benefit analysis from the perspectives of donor, recipient and society in general' (2006: 415). Evaluating and reporting the effects of CSR practice is an 
exceptionally important issue and one we will return to in the next section because there is perhaps here an opportunity for public relations to fulfil the public service aspirations referred to above.

However it must be noted that in respect to CSR many companies frequently allude, in deontological language, to their responsibilities or duties to the community, or society as a whole. Lord Raynor, when he was Chairman of Marks and Spenser stated: 'There rests on all companies, particularly large organisations like ours, a responsibility to assist through donations and help, the charities and agencies which exist in the community' (quoted in L'Etang 1996: 91). L'Etang (2006) makes the point that such aspirational claims are seldom matched by the practice of corporations. She argues that a deontological approach to CSR would focus on the motivation behind the programme, because seeking benefit from carrying out your responsibilities would not be ethical. From this perspective a CSR programme needs to demonstrate that it is motivated by duty, and not self-interest (enlightened or any other kind). If a company were attempting to improve its image or reputation via community involvement then it would be treating beneficiaries as a means and not as ends in themselves and thus breaking Kant's categorical imperative. L'Etang (2006) points out that if corporations took on board Kantian principles then their CSR programmes might be managed rather differently. If the beneficiaries of CSR are to be treated as ends in themselves then they should be accorded equal status in defining and developing their relationship with the corporation and indeed in designing the CSR programmes they are meant to be benefitting from. If the language of the classic ethical theories is adopted to explain and justify CSR but companies do not fulfil the full implications of these ethical doctrines then they can leave themselves open to the charge of cynicism.

When reading corporate literature on CSR it becomes clear that companies sometimes do not restrict themselves to justifying the activity solely from a utilitarian, or a Kantian perspective. Robert Clarke, Chairman of United Biscuits, states: 'Our commitment to community involvement stems from our strong sense of social responsibility combined with the realization of the commercial benefits that it brings ... a generous and far-reaching sense of community responsibility - are essential to effective long-term business performance' (quoted in Newman 1995: 99). L'Etang notes that in 
'many cases corporate literature is confusing because it appears to appeal to both utilitarian and Kantian principles yet apparently delivers on neither' (L'Etang 1996: 93). This point, while indisputable, can perhaps be explained to some extent by the fact, noted above, that the classic ethical doctrines need to be qualified by each other in order to arrive at an ethic which balances rights and obligations with the 'greater good'. It could certainly be argued that, given that moral philosophers have found it difficult to come to a wholly satisfactory resolution when debating the relative merits of the classic ethical doctrines, it would be asking a lot to expect business managers or public relations practitioners to avoid some confusion when dealing with complex ethical debates. Nevertheless whether or not a company appeals to a combination of ethical doctrines to justify its CSR policies and practices it should be expected to make a meaningful and committed attempt to fulfil the requirements of those ethical doctrines. Thus a deontological approach, motivated by the principle which regards others as intrinsically and not just instrumentally valuable will entail a commitment to genuinely 'engage' with stakeholders to find out how the CSR process can really fulfil their needs. This is quite different from merely 'managing' them and ultimately exploiting the process for the reputational benefits of the corporation. A utilitarian approach which is meant to ensure benefit to all sides should be prepared to measure and demonstrate that benefit clearly and transparently. The final two sections of this chapter explore these two key issues of engagement with and responsiveness to stakeholders and the measurement and evaluation of CSR practices in more detail.

\section{Evaluating and reporting CSR policy and practice}

L'Etang (2006) has noted that it has long been argued that PR practitioners need to develop more comprehensive research and evaluation skills and we would suggest that this is particularly important in respect to CSR initiatives in communities. Recent commercial communications research and academic analysis has also emphasised this

point. For instance Richard Coope, Head of CSR practice at CTN, commenting on the 2004 CSR Online Survey by CTN Communications notes:

The UK's top companies are still not taking CSR seriously, making little effort to improve their online communication of CSR to investors and other key stakeholders. ... Despite a lot of noise about the growing importance of CSR to 
reputation and brand, most companies still seem content to produce long-winded CSR reports. These are more often designed to meet the requirements of the regulators and specialist CSR agencies than to connect with the general public. Only the most committed net visitor will be prepared to plough through a 90 page long pdf (see www.csr-survey.org).

Owen also highlights this point commenting that recent years 'have witnessed a significant increase in the number of major companies in Europe, the USA and Australia proclaiming their social responsibility credentials, and backing up their claims by producing substantial paper, or web-based, environmental, and more recently, social and sustainability reports' (2005: 1). Accompanying this expansion in the reporting of CSR activity companies have also claimed that they now carry out much more research into stakeholder views and requirements. Scottish Power's statement in their 2003 CSR report is fairly typical. Scottish Power state that they: "commissioned research to establish stakeholders views on the relevant issues to cover in this report. We also incorporated multi-stakeholder feedback from previous Scottish Power Environmental Sustainability and Community reports' (quoted in Owen 2005: 7). This all seem very laudable however Scottish Power's own assurance process does tend to highlight that while the company's activity in regard to stakeholder research is to be commended the actual use to which this research is being put is less clear. A recent trend in company CSR reporting is to have one of the specialist CSR bodies verify the report in much the same way as an accountancy company verifies the financial annual report. Interestingly csrnetwork's Verification Statement for Scottish Power's CSR report concludes: 'Commendably, formal dialogue is undertaken with selected stakeholder groups to understand the information they require. Future reports would benefit from an explanation of how this, and the constant dialogue that happens during the running of the business, informs the issues, actions and performance data included in the report' (quoted in Owen 2005: 10). Carrying out research and reporting it has happened is all very well but it is vitally important that a company spell out clearly and in detail how they are evaluating stakeholder feedback and what impact the results of this research actually has on corporate decision making. There is an opportunity here for PR but practitioners need to do more to develop the research, evaluation and reporting skills which will enable them to monitor the attitudes and expectations of stakeholders more successfully. The same 
skills will also enable them to demonstrate how the company's CSR policies and practice have actually benefited stakeholders as well as the corporation in a much more transparent way. A recent initiative by Business in the Community sets out 'principles of measurement' which would make an excellent starting point for public relations practitioners wishing to develop more robust methodologies for both assessing stakeholder needs and measuring CSR impacts (see 'More than making money' at www.bitc.org.uk).

It is vitally important that public relations practitioners engage more competently in research and evaluation in this area because it is becoming clear that in the absence of wholly transparent corporate communication in this area stakeholders will increasingly today access alternative sources of information to find out about, and make up their own minds about, a company's activity. A recent (2007) major CSR survey carried out by Fleishman Hillard International Communications and the National Consumers League in the USA has shown that amongst consumers 'online sources' and 'word-of-mouth' vastly outweigh traditional media sources as preferred ways to learn about a company's CSR record. Reponses indicated that consumers increasingly rely on the Internet to find out about CSR-related information but not in ways that will provide much comfort for corporations. Only $7 \%$ of respondent said they would rely on the company website whereas $49 \%$ said they would use Internet search engines or the Websites of discussion groups. Additionally $77 \%$ of consumers feel that word-of-mouth recommendations from peers are more powerful than recommendations from traditional media outlets. The authors of the report note that: 'These findings, taken together, may indicate that traditional media sources may be lacking in credibility because the information they disseminate is viewed as incomplete, censored, edited, and therefore tarnished in some way' (www.csrresults.com).

In today's information society the corporate Website which seems to be the natural mechanism to use to report CSR policies and practices is then in danger of being bypassed by consumers and other stakeholders. Coupland notes 'With interest from potential customers and employees to current shareholders, the remit of attracting, entertaining or satisfying the Website reader is a complex one...This has relevance as companies are increasingly competing in discursive space where winning the "argument" 
is important' (2005: 356). If, as seems to be the case, consumers and other stakeholders are not engaged by current CSR reporting processes then this is an issue that must be taken seriously by PR practitioners. A recent study of corporate websites by Capriotti and Moreno notes that in respect to CSR 'the websites assume a mainly unidirectional/expositive function, focusing on the presentation of the information content. A high predominance of expositive resources (graphic and audiovisual) rather than interactive resources is observed' (2007: 89). In other words information is displayed for an assumed passive reader but there is little attempt to use the interactive capabilities of the Internet to engage with stakeholders and potential stakeholders.

\section{Engagement and responsiveness in CSR polices and practice}

We noted above that simply publishing increasingly elaborate and lengthy CSR reports is not enough to convince stakeholders that their views are being taken into account and more importantly being acted upon at the corporate governance level. This means that the public relations role in CSR should not just be about presenting information it is about engaging with stakeholders and most importantly it is about demonstrating responsiveness to stakeholder views. In the Accountability Rating Report 2006 of global corporations by AccountAbility, the global think-tank on organisational and corporate accountability, two of the key measurement factors they list in their analysis are 'stakeholder engagement' and 'governance'. They define these factors as follows:

Stakeholder engagement - Does the company engage in dialogue with people who have an interest in, may be affected by, or may affect its business?

Governance - Do senior executives and the advisory board properly consider stakeholder issues when setting strategy and formulating corporate policy? (www.accountabilityrating.com)

In respect to the issue of stakeholder engagement the study by Capriotti and Moreno (2007) would seem to indicate that the engagement process is lacking or at best in its infancy. In respect to the websites they studied that note that:

$[\mathrm{N}] \mathrm{o}$ evaluation tools (such a interactive opinion polls, opinion forms, etc.) are provided, nor are there interactive feedback tools (such as chat rooms, forums, blogs, etc.) that would allow visitors to interact with the companies or with other people about CSR topics in real time...They are in a very initial phase of 
interaction or dialogue with their publics, considering that the resources used to present the information are mainly expositive, and the feedback resources available are minimal. The use of corporate websites for CSR issues is partial and limited, focusing primarily on the dissemination of information, rather than favouring dialogue and interaction with different publics' (Capriotti and Moreno 2007: 89).

Owen suggests that the crucial question from a stakeholder accountability perspective has to be whether 'the engagement and dialogue processes they are invited to participate in do meaningfully influence specific aspects of corporate decision making, and in particular can lead to situations where their interests prevail over those of shareholders in matters of distributional conflict' (2005: 10-11). He notes that a particularly noteworthy level of responsiveness to stakeholder concerns appears in the Co-operative Bank's 2002 Partnership Report. The Co-operative Bank's approach is rare however and more typically, suggests Owen, commentary in CSR reports regarding responsiveness to stakeholder feedback is couched in more general and vague terms making it impossible to gauge 'how, if at all, stakeholder feedback influences corporate strategic decision making'(2005: 9).

CSR reports may devote significant space to describing the stakeholder dialogue processes that have taken place but according to Owen 'For stakeholder accountability to be established and associated reporting exercises to be meaningful in empowerment terms, a far more pluralistic form of corporate governance must be instituted' (2005: 26). As we noted above a key demonstration of good will from the deontological perspective is the demonstration that that the company/stakeholder relationship in respect to CSR policies and activities are based on the mutual recognition of rights and responsibilities on both sides. In respect to this issue of corporate governance many corporations report the inclusion of external members on their advisory panels which help shape CSR policies and practices. While such measures are a step in the right direction toward more accountable and transparent corporate governance structures Owen notes:

[I]t is debatable as to how much such initiatives achieve in terms of empowering stakeholders and thereby democratising the whole CSR process. The crucial point here is that the external participants (as far as may be ascertained) are appointed by corporate management, rather than being elected by those they purport to represent. Quite bluntly, these individuals represent no-one but themselves and are therefore directly accountable to no-one but themselves. Significantly forums 
at which stakeholder groups (predominantly employee and local community groups) are directly represented are confined to consultative committee type structures, completely separated from the key strategic decision making arena' (2005: 14).

How a company responds to its stakeholders is key here, AccountAbility AA1000 issued an Assurance Standard for CSR relationships and they highlight the key principle of responsiveness which they state requires 'the Assurance provider evaluate whether the reporting organisation has responded to stakeholder concerns, policies and relevant standards and adequately communicated these responses in its report' (2003: 18). However this should be viewed as an important opportunity for PR representatives who can facilitate a process which will offer stakeholders a meaningful voice in the corporate decision-making arena and thereby demonstrate concretely the deontological concepts of duty and responsibility which underpins many of the statements in CSR documentation. Indeed it is a role they must fulfil in order to avoid the charge that their role, and that of CSR initiatives more generally, is nothing more than the cynical instrumental exploitation of stakeholders for benefit of corporate reputation.

\section{Case Study: CSR, the credit crunch and stakeholder communication in the Irish banking sector}

The Irish banking sector is in some senses an extreme example, and in other ways entirely typical, of the catastrophe which overtook financial institutions around the world at the end of 2008 and early 2009. The fracturing of the global financial system has had a disastrous impact on all Irish financial institutions. Irish banks listed on the London Stock Exchange saw their share prices plunge 90\% in the twelve months up to December 2008 (Bloomberg.com 21/01/09). Facing a financial sector meltdown at the end of 2008 the Irish government took the unprecedented step of guaranteeing all bank deposits and debts in Irish banks for two years (a loan guarantee worth over 550 billion euro, a sum which exceeds the German government's guarantee to German banks and which amounts to almost three times Ireland's annual GDP of 160 billion euro). It also announced a multibillion euro bailout for three of the biggest banks, Bank of Ireland, Allied Irish Bank and the Anglo Irish Bank taking a 25\% stake in each and it has since nationalised several 
banks in the sector. In March 2009 the Irish government announced a plan to buy up the toxic debts of most of the Irish registered banks, both domestic and foreign owned, at a potential cost of 80 billion euro. One price that the domestic banks have had to pay for this government help was to sign up to a range of Irish Banking Federation requirements one of which is that they will produce joint bi-annual transparent CSR reports and present them to the office of the Irish Finance Minister. This was quite a culture change for Irish banks some of which, in what was a relatively unregulated system, had never provided any kind of dedicated CSR report in the past.

This case study compares the CSR activity and reporting of two banks operating in Ireland. One is the Dutch owned Rabobank which entered the Irish market by purchasing the Irish bank ACC in 2002, the other is the Bank of Ireland, the last remaining bank listed on the Irish Stock Exchange. One thing which the Dutch bank brought with it to the Irish financial sector was a focus on CSR issues and a concern to engage with a range of stakeholders on all aspects of its business practice. This was the way it operated in the Netherlands and it claimed to import this culture to all its overseas operations including its Irish subsidiary. Given that the Irish taxpayer is now a partial owner of the Bank of Ireland one may also expect to see a high level of transparency in respect to its CSR activities and a commitment to dialogue with its stakeholders. Following the approach of Capriotti and Moreno (2007) this case study will investigate best practice in CSR disclosure and stakeholder engagement by analyzing the presence of key CSR indicators on the Websites of the respective banks. It will also assess the nature of the stakeholder communication, with a particular focus on how 'expositive' or 'interactive' (Caprioti and Moreno 2007: 89) the communication approach is. A predominance of expositive communication would mean the bank relied on merely displaying information about its CSR activities, which, as we know from the Fleishman Hillard (2007) study cited above does not meet with the approval of stakeholders. A high level of 'interactive' communication capability is viewed as potentially resolving this communication barrier between stakeholders and corporations (Capriotti and Moreno 2007). Key to the development of interactive communication, on this view, are online technologies and social media which can facilitate in dialogue (blogs, forums), create opportunities for feedback (dedicated email contact addresses, online opinion forms) and 
'converse' with stakeholders through the new Web: 2 media (Facebook, Twitter). Of course organizations may exaggerate claims that they engage in interaction with stakeholders therefore we will drill down into the information presented in the websites to assess the real level of stakeholder engagement and just how much the views of relevant stakeholders actually influence CSR policy and practice.

In respect to the issue of the presence of CSR indicators this case study investigation has, like previous studies (O'Donovan et al 2001; Capriotti and Moreno 2007) relied upon a combination of internationally recognized CSR indices to construct a table of best practice measurement. The CSR indicators identified are based on the requirements for disclosure in CSR reporting from the following sources: World Business Council for Sustainable Development (2000), United Nations Global Compact (2002), Global Reporting Initiative (2006) and Business in the Community (BITC). BITC operates in both the UK and the Republic of Ireland and the categories adopted are from their 2007 Responsibility Index. The CSR issues are listed in the table below (Fig. 1) along with a brief definition and an indication of the reference source.

Figure 1: CSR issues, definitions and indicator sources

\begin{tabular}{|l|l|l|}
\hline CSR Issue & Definition & Source \\
\hline Corporate governance & $\begin{array}{l}\text { Explanation of the organisation's } \\
\text { decision/policy making structure and } \\
\text { how it ensures transparency in } \\
\text { respect to accountability and } \\
\text { disclosure. }\end{array}$ & $\begin{array}{l}\text { WBCSD (2000); GRI (2006); BITC } \\
\text { 2007) }\end{array}$ \\
\hline Employee rights & $\begin{array}{l}\text { Explanation of the organisation's } \\
\text { systems of contract, evaluation, } \\
\text { promotion and dismissal. }\end{array}$ & $\begin{array}{l}\text { WBCSD (2000); UNGC (2002); GRI } \\
\text { (2006); BITC (2007) }\end{array}$ \\
\hline Human rights & $\begin{array}{l}\text { Explanation of the organisation's } \\
\text { approach to human rights } \\
\text { (discrimination, child labour etc.) }\end{array}$ & $\begin{array}{l}\text { WBCSD (2000); UNGC (2002); GRI } \\
\text { (2006); BITC (2007) }\end{array}$ \\
\hline Economic impacts & $\begin{array}{l}\text { Explanation of the organisation's } \\
\text { economic impact at the local, } \\
\text { regional, national and supranational } \\
\text { levels. }\end{array}$ & $\begin{array}{l}\text { WBCSD (2000); GRI (2006); BITC } \\
\text { (2007) }\end{array}$ \\
\hline Social impacts & $\begin{array}{l}\text { Explanation of the organisation's } \\
\text { activities in relation to social issues. }\end{array}$ & $\begin{array}{l}\text { WBCSD (2000); GRI (2006); BITC } \\
\text { (2007) }\end{array}$ \\
\hline Environmental impacts & $\begin{array}{l}\text { Explanation of the organisation's } \\
\text { involvement ind inction } \\
\text { environmental issues. on }\end{array}$ & $\begin{array}{l}\text { WBCSD (2000); UNGC (2002); } \\
\text { GRI (2006); BITC (2007) }\end{array}$ \\
\hline Stakeholder relationships & $\begin{array}{l}\text { Explanation of the organisation's } \\
\text { actions in relation to its } \\
\text { stakeholders/publics (shareholders, } \\
\text { customers, and suppliers). }\end{array}$ & $\begin{array}{l}\text { WBCSD (2000); GRI (2006); BITC } \\
\text { (2007) } \\
\text { ethical framework in relation to its }\end{array}$ \\
\hline
\end{tabular}




\begin{tabular}{|c|c|c|}
\hline & $\begin{array}{l}\text { business activities and its } \\
\text { stakeholders/publics. }\end{array}$ & \\
\hline External criteria on CSR & $\begin{array}{l}\text { Explanation of the organisation's } \\
\text { incorporation of national and } \\
\text { international criteria on CSR. }\end{array}$ & $\begin{array}{l}\text { WBCSD (2000); GRI (2006); BITC } \\
(2007)\end{array}$ \\
\hline
\end{tabular}

Key:

World Business Council for Sustainable Development (2000), United Nations Global Compact (2002), Global Reporting Initiative (2006), Business in the Community (2007)

What should be made clear, about the reporting criteria in the table above, is that it is not enough for the organization to merely claim it is committed to a particular CSR principle, e.g. environmental impact. The minimum requirements are that it must present a clear explanation of what it means by this indictor and how it applies it in practice.

Figure 2. Presence of CSR issues on the corporate websites (including online CSR reports/corporate annual reports) of Rabobank and Bank of Ireland.

\begin{tabular}{|c|c|c|}
\hline CSR Issue & Rabobank/ ACC & Bank of Ireland \\
\hline Corporate governance & V & V \\
\hline Employee rights & $\sqrt{ }$ & V \\
\hline Human rights & $\sqrt{ }$ & \\
\hline Economic impacts & $\sqrt{ }$ & \\
\hline Social impacts & $\sqrt{ }$ & $\mathrm{V}$ \\
\hline Environmental impacts & 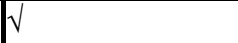 & V \\
\hline Stakeholder relationships & $\sqrt{ }$ & V \\
\hline Corporate ethics & $\sqrt{ }$ & V \\
\hline External criteria on CSR & V & \\
\hline
\end{tabular}

As can be seen from Figure 2 the presence of CSR issues on corporate websites in Rabobank and Bank of Ireland (websites accessed 02/02/2011 and 03/02/2011) reveal an apparently fairly similar picture. Most key CSR issues are present on the website of the Bank of Ireland and all are present on the Rabobank website. The exceptions being that there is no explanation of how the Bank of Ireland in its business activities discharges its 
responsibilities toward human rights or the economic impact of its activities. Interestingly despite the bank being listed as a member of Business in the Community in both Northern Ireland and the Republic of Ireland there is no indication of how it applies the BITC Responsibility Index in practice. It should also be noted that some of the documentation of the Bank of Ireland's CSR activity actually appears in the joint Irish Banking Federation CSR report submitted bi-annually with the other Irish owned banks in the Irish financial sector. As noted above, this is to comply with the requirements imposed upon them by the Irish government after the financial bailout of these institutions. This joint report (last published $22^{\text {nd }}$ September 2010) is included as a pdf file on the Bank of Ireland website, as it is on websites of the 6 other Irish banks covered under the Credit Institutions (Financial Support) Scheme.

In contrast to the Bank of Ireland how Rabobank engages with each of the CSR issues is explained and discussed in depth with a wealth of pertinent information and case study examples of the banks activities. The information is not just presented as written text there is frequent use of audio-visual material such as podcasts, webcast and web films. There is also a detailed explanation of stakeholder dialogue on the webpage dedicated to this issue where 20 different stakeholder groups, which the bank regularly consults on policy and practice issues, are listed. Rabobank explains in detail how it measures its practice against a range of CSR indicators including the United Nations Global Compact and the Global Reporting Initiative and it publishes the reports of several independent CSR rating agencies including the Corporate Sustainability Assessment of SAM (Sustainable Asset Management Group) and Oekom. It should be emphasised that the bank is not selective in it reporting in this area. It does highlight that it received an A+ rating from the Global Reporting Initiative but publishes in full Oekom's Corporate Rating report which awards it a $\mathrm{C}+$, a rating which suffered to some extent because of its relatively poor score in 'eco-efficiency'. The fact that both banks appear to tick most or all of the boxes in regard to the presence of CSR issues in their corporate reporting should not obscure the fact that on closer analysis the Bank of Ireland falls along way behind Rabobank when it comes to transparency and detailed explanation in respect to its actual CSR policy and practice. 
Figure. 3 Expositive and interactive resources.

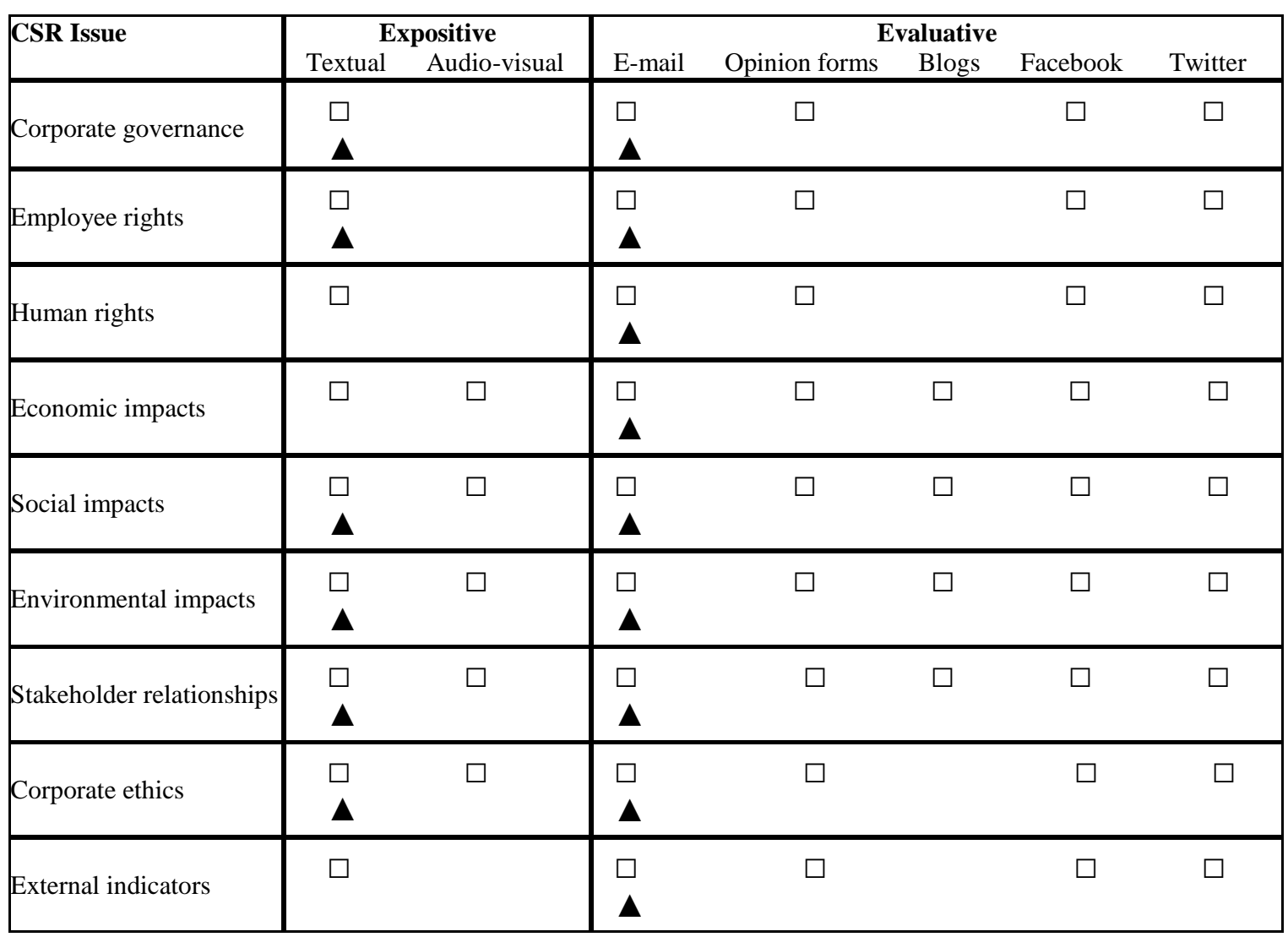

- Rabobank

$\Delta$ - Bank of Ireland

A key difference between the banks is immediately apparent in Figure 3 when one assesses how the two banks deploy the interactive capabilities of new media technologies to open up the potential for dialogue and engagement with stakeholders. The only interactive resource on the Bank of Ireland website is the email facility. It is a general email address so it theoretically can be used to contact the management on any of the CSR issues. In contrast Rabobank has several dedicated email addresses in the different CSR areas to allow the user to engage with a specific expert on an issue and there are also contact forms on each CSR webpage where issues can be raised or a complaint made about Rabobank's CSR policies and activities or that of any of its clients. In either case the bank promises to provide a written answer within 30 days. Rabobank have an easily accessible fully interactive blog (available via RSS feed) which various staff members 
from across the organisation participate in and comments are invited from all stakeholders. Many of the topics focus, as one would expect, on issues like investment or pensions but debates about the environment and social and ethical issues (e.g. investing in countries with poor human rights records) are also present. Rabobank's website also provides links to its Web: 2 social media such as Facebook and twitter which are up to date and widely used by a wide range of stakeholders.

The banking industry underpins capitalism in a uniquely fundamental way, at least this was the message which Western governments sought to communicate to citizens during the recent massive bailouts of the financial sector. But if it is the case that the financial sector is fundamental to late capitalist society then this invites some further meditation on the relationship between financial institutions and society. Western governments presumed an obligation or responsibility to the banks and this was the justification for propping them up with enormous amounts of tax payer's money. This does lead to an interesting question. Does this obligation work both ways? Do banks now have an additional responsibility to society? It seems that some banks such as Rabobank, now the only AAA rated bank in Ireland, take the view that CSR is an integral part of what underpins their business activities while others, such as the Bank of Ireland, despite being partially owned by the ordinary citizens of Ireland offer very little detailed explanation of how CSR is integrated with their business activities. The respective corporate websites, increasingly the public face of all organisations, illustrate this difference.

\section{Conclusion}

With regard to the role of public relations in CSR, there would appear to be two clear choices. Public relations practitioners can use CSR as just another element in the 'the creation, or "engineering" of consent' in order to foster 'a favourable and positive climate of opinion toward the...institution' (Steinberg 1975: 15 quoted in Gandy 1992: 133). Or they can try to realise the idea that public relations can also serve the public interest (Grunig 1989; Broom 2005). This will involve making genuine attempts to discover the requirements of community stakeholders through real engagement and 
partnership. To achieve this the stakeholder model, built as it is upon deontological foundational assumptions, is a prerequisite. As we have seen this model argues that a corporation should take account of the interests of all the groups which have a stake in it. In respect to CSR it would mean that all stakeholder groups including the potential beneficiaries of such programmes should be able to engage in debates about CSR policy and ultimately contribute to the decision-making process. This would demonstrate that companies are treating the beneficiaries of corporate social responsibility with 'good will' and as ends in themselves. When they first formulated it, in the early 1980's, Evan and Freeman admitted that a stakeholder approach may seem 'utopian' (1993: 265), but it would appear that more recently the tide has turned to an extent and the stakeholder concept has infiltrated business and political thinking to a remarkable degree.

It must be said however, that while the stakeholder concept has apparently achieved widespread acceptance much more needs to be done to put it into practice and that public relations - utilising the full potential of new information and communication technologies - can and should play a key role in this task. As the key organisational group responsible for liaising with stakeholders public relations practitioners are best placed to help design and shape a participatory process to meet the needs of stakeholders. They are also in a position to capture stakeholder views through qualitative and quantitative measurement. All this will involve developing more robust research methodologies for gathering stakeholder perspectives, a commitment to report and evaluate these viewpoints completely and transparently and a willingness to engage with and respond to stakeholder needs and concerns.

\section{Questions for discussion}

1. Assess Milton Friedman's claim that 'there is one and only one social responsibility of business - to use its resources and engage in activities designed to increase its profits' (1993: 254)?

2. Assess the practicalities of achieving Evan and Freeman's view that stakeholder groups have 'a right not to be treated as a means to some end, and therefore must 
participate in determining the future direction of the firm in which they have a stake' (1993: 255)?

3. In what ways may CSR highlight a dilemma (L'Etang 2006) at the heart of PR practice?

The remaining questions require you to research your own case study example of CSR practice. Chose a company and analyse the documentation - its website is a good place to start - which outlines and explains its CSR programme(s).

4. Does the company tend to adopt the language of 'utilitarianism' or the language of 'deontology' when explaining and justifying its CSR initiatives?

5. What independent reporting indices does the organisation use in its CSR reporting? Does its report reflect recognised indicators from, for example, the United Nations Global Compact (2002), the Global Reporting Initiative (2006) or the UK/Ireland Business in the Community (BITC) guidelines?

6. Assess the overall standard of reporting and evaluation of the company's CSR activities. Is this clear, detailed and transparent?

7. Does the CSR report include research on stakeholder feedback? If so how is this reported? Which stakeholders are cited?

8. How does the company use its website to measure stakeholder views on CSR issues? For example, does the website include evaluation tools such as online opinion forms?

9. Does the website incorporate interactive feedback tools (e.g. chat rooms, forums, blogs, etc.)? Is there evidence that Web 2.0 capabilities are being utilised to their full potential?

10. How are stakeholders included in corporate governance in respect to CSR, i.e. does the organisation explain how their views ultimately feed into decision making surrounding policy and practice?

\section{Suggested further reading}


Capriotti, P. and Moreno, A. (2007) 'Corporate citizenship and public relations: The importance and interactivity of social responsibility issues on corporate websites', Public Relations Review 33, 84-91

Cutlip, S.M., Center, A.H. and Broom, G.M. (2000) Effective Public Relations ( $8^{\text {th }}$ Edition), Prentice Hall

Daugherty, E.L. (2001) 'Public relations and social responsibility', in R.L. Heath (Ed.) Handbook of Public Relations, Sage

Day, K.D., Dong, Q. and Robins, C. (2001) 'Public relations ethics: an overview and discussion of issues for the $21^{\text {st }}$ century', in R.L. Heath (Ed.) Handbook of Public Relations, Sage

Dienhart, J.W. (2000) Business, Institutions, Ethics, Oxford University Press

Evan, W.M. and Freeman, R.E. (1993) 'A stakeholder theory of the modern corporation: Kantian capitalism' in G.D. Chryssides and J.H. Kaler (eds) An Introduction to Business Ethics, Chapman and Hall.

Freidman, M., (1993) 'The social responsibility of business is to increase its profits' in G.D. Chryssides and J.H. Kaler (eds) An Introduction to Business Ethics, Chapman and Hall.

L'Etang, J. (2006) 'Corporate responsibility and public relations ethics' in L'Etang, J. and Pieczka, M. (Eds) Public Relations: Critical Debates and Contemporary Practice, Lawrence Erlbaum Associates

Moloney, K. (2006) Rethinking Public Relations (2 ${ }^{\text {nd }}$ Edition), Routledge 
Owen, D. (2005) 'Corporate Social Reporting and Stakeholder Accountability: The Missing Link' at www.nottingham.ac.uk/business/ICCSR/research/paperseries.html. 